\title{
EDITORIAL
}

\section{Multilevel developmental perspectives on child maltreatment}

\author{
DANTE CICCHETTI $^{a}$ AND SHEREE L. TOTH ${ }^{b}$ \\ ${ }^{a}$ University of Minnesota Institute of Child Development; and ${ }^{b}$ University of Rochester Mt. Hope Family Center
}

The knowledge base on the effects of child maltreatment on developmental processes and outcomes has increased exponentially since the early stages of this research were initiated approximately 50 years ago. Although early studies were fraught with methodological flaws and limitations (for critical reviews, see Aber \& Cicchetti, 1984; Cicchetti \& Aber, 1980), current studies are empirically rigorous, and both intervention and social policy initiatives are increasingly informed by the results of research investigations (Cicchetti \& Toth, 1993, 2000). A consensus now exists that child maltreatment exerts a broad impact across multiple domains and systems of biological and psychological development, beginning at the time the trauma occurs and, unless intervention or other protective factors are operative, extending into adulthood (Cicchetti \& Toth, in press; Jaffee \& Christian, 2014; Masten \& Cicchetti, 2010; Moffitt \& the Klaus-Grawe 2012 Think Tank, 2013; Toth, Gravener-Davis, Guild, \& Cicchetti, 2013).

Moreover, the sophistication of research conducted on child maltreatment has increased substantially. Technological and statistical advances have opened up more avenues for elucidating the mechanisms and processes that contribute to the deleterious consequences associated with maltreatment, and to the development of resilient functioning in the face of adversity, as well as for shedding light on the development and implementation of effective prevention and intervention strategies (Bernard et al., 2012; Cicchetti, 2013; Cicchetti, Rogosch, \& Toth, 2006; Dozier, Peloso, Lewis, Laurenceau, \& Levine, 2008; Toth, Petrenko, Gravener Davis, \& Handley, in press).

In addition, the gains in scientific knowledge that have accrued have resulted in a dramatic growth in the comprehen-

\section{References}

Aber, J. L., \& Cicchetti, D. (1984). Socioemotional development in maltreated children: An empirical and theoretical analysis. In H. E. Fitzger-

Preparations of this Special Issue was facilitated by grants from the National Institute of Drug Abuse (R01DA017741), the National Institute of Mental Health (R01MH091070), and the Spunk Fund, Inc.

Address correspondence and reprint requests to: Dante Cicchetti, Institute of Child Development, University of Minnesota, 51 East River Road, Minneapolis, MN 55455. E-mail: cicchett@umn.edu. sion of the genetic and epigenetic, neurobiological, neuroendocrinological, immunological, cognitive/representational, and socioemotional processes underlying both the developmental pathways to and the consequences of child maltreatment (Cicchetti \& Toth, in press; Danese et al., 2008; DeBellis, 2001, 2005; Heim \& Binder, 2012; Heim, Newport, Mletzko, Miller, \& Nemeroff; 2008; Miller, Chen, \& Parker, 2011; Pollak, Cicchetti, Hornung, \& Reed, 2000; Pollak, Cicchetti, Klorman, \& Brumaghim, 1997; Tarullo \& Gunnar, 2006; Weder et al., 2014; Yang et al., 2013). One outgrowth of these advances in understanding developmental processes has been that in order to grasp fully the complexity inherent to the examination of the human mind, normal and abnormal, it is important that a multiple levels of analysis approach and an interdisciplinary perspective be incorporated into the research armamentaria of maltreatment investigators (Cicchetti, 2008; Cicchetti \& Dawson, 2002; Cicchetti \& Valentino, 2007).

Prevention and intervention scientists need to incorporate measures at multiple levels of analysis into randomized control trial interventions to more fully capture and evaluate intervention effects and mechanistic processes consistent with theory (Cicchetti \& Blender, 2006; Cicchetti \& Gunnar, 2008; Hinshaw, 2002; Toth et al., in press). The contributions to this Special Issue exemplify the growth of research on child maltreatment from a multilevel perspective. As research of this nature continues to burgeon, findings can be translated into the design, implementation, and evaluation of developmentally sensitive interventions that can contribute to reducing maladaptation and psychopathology and to promoting resilience. ald, B. Lester, \& M. Yogman (Eds.), Theory and research in behavioral pediatrics (Vol. 2, pp. 147-205). New York: Plenum Press.

Bernard, K., Dozier, M., Bick, J., Lewis-Morrarty, E., Lindheim, O., \& Carlson, E. (2012). Enhancing attachment organization among maltreated children: Results of a randomized clinical trial. Child Development, 83, 623-636. Cicchetti, D. (2008). A multiple-levels-of-analysis perspective on research in development and psychopathology. In T. P. Beauchaine \& S. P. Hinshaw (Eds.), Child and adolescent psychopathology (pp. 27-57). Hoboken, NJ: Wiley.

Cicchetti, D. (2013). Resilient functioning in maltreated children: Past, present, and future perspectives. Journal of Child Psychology and Psychiatry, $54,402-422$. 
Cicchetti, D., \& Aber, J. L. (1980). Abused children-abusive parents: An overstated case? Harvard Educational Review, 50, 244-255.

Cicchetti, D., \& Blender, J. A. (2006). A multiple-levels-of-analysis perspective on resilience: Implications for the developing brain, neural plasticity, and preventive interventions. Annals of the New York Academy of Sciences, 1094, 248-258.

Cicchetti, D., \& Dawson, G. (2002). Multiple levels of analysis. Development and Psychopathology, 14, 417-420.

Cicchetti, D., \& Gunnar, M. R. (2008). Integrating biological processes into the design and evaluation of preventive interventions. Development and Psychopathology, 20, 737-743.

Cicchetti, D., Rogosch, F. A., \& Toth, S. L. (2006). Fostering secure attachment in infants in maltreating families through preventive interventions. Development and Psychopathology, 18, 623-649.

Cicchetti, D., \& Toth, S. L. (Eds.). (1993). Child abuse, child development, and social policy. Norwood, NJ: Ablex.

Cicchetti, D., \& Toth, S. L. (Eds.) (2000). Social policy implications of research in developmental psychopathology [Special Issue]. Development and Psychopathology, 12, 551-885.

Cicchetti, D., \& Toth, S. L. (in press). Child maltreatment and developmental psychopathology: A multilevel perspective. In D. Cicchetti (Ed.), Developmental psychopathology (Vol. 3, 3rd ed.). Hoboken, NJ: Wiley.

Cicchetti, D., \& Valentino, K. (2007). Toward the application of a multiplelevels-of-analysis perspective to research in development and psychopathology. In A. S. Masten (Ed.), Multilevel dynamics in developmental psychopathology: The Minnesota Symposia on Child Psychology (Vol. 34, pp. 243-284). Mahwah, NJ: Erlbaum.

Danese, A., Moffitt, T. E., Pariante, C. M., Ambler, A., Poulton, R., \& Caspi, A. (2008). Elevated inflammation levels in depressed adults with a history of childhood maltreatment. Archives of General Psychiatry, 65, 409-416.

DeBellis, M. D. (2001). Developmental traumatology: The psychobiological development of maltreated children and its implications for research, treatment, and policy. Development and Psychopathology, 13, 539-564.

DeBellis, M. D. (2005). The psychobiology of neglect. Child Maltreatment, 10, 150-172.

Dozier, M., Peloso, E., Lewis, E., Laurenceau, J. P., \& Levine, S. (2008). Effects of an attachment-based intervention on the cortisol production of infants and toddlers in foster care. Development and Psychopathology, 20, 845-859.

Heim, C., \& Binder, E. B. (2012). Current research trends in early life stress and depression: Review of human studies on sensitive periods, geneenvironment interactions, and epigenetics. Experimental Neurology, 233, $102-111$.
Heim, C., Newport, J. D., Mletzko, T., Miller, A. H., \& Nemeroff, C. B. (2008). The link between childhood trauma and depression: Insights from HPA axis studies in humans. Psychoneuroendocrinology, 33, 693-710.

Hinshaw, S. P. (2002). Intervention research, theoretical mechanisms, and causal processes related to externalizing behavior problems. Development and Psychopathology, 14, 789-818.

Jaffee, S. R., \& Christian, C. W. (2014). The biological embedding of child abuse and neglect: Implications for policy and practice. Social Policy Report, 28, 3-19.

Masten, A. S., \& Cicchetti, D. (2010). Developmental cascades. Development and Psychopathology, 22, 491-495.

Miller, G. E., Chen, E., \& Parker, K. J. (2011). Psychological stress in childhood and susceptibility to the chronic diseases of aging: Moving toward a model of behavioral and biological mechanisms. Psychological Bulletin, 137, 959-997.

Moffitt, T. E., \& the Klaus-Grawe 2012 Think Tank. (2013). Childhood exposure to violence and lifelong health: Clinical intervention science and stress biology research join forces. Development and Psychopathology, $25,1619-1634$

Pollak, S. D., Cicchetti, D., Hornung, K., \& Reed, A. (2000). Recognizing emotion in faces: Developmental effects of child abuse and neglect. Developmental Psychology, 36, 679-688.

Pollak, S. D., Cicchetti, D., Klorman, R., \& Brumaghim, J. (1997). Cognitive brain event-related potentials and emotion processing in maltreated children. Child Development, 68, 773-787.

Tarullo, A. R., \& Gunnar, M. R. (2006). Child maltreatment and the developing HPA axis. Hormones and Behavior, 50, 632-639.

Toth, S. L., Gravener-Davis, J. A., Guild, D. J., \& Cicchetti, D. (2013). Relational interventions for child maltreatment: Past, present, and future perspectives. Development and Psychopathology, 25, 1601-1617.

Toth, S. L., Petrenko, C. L. M., Gravener Davis, J., \& Handley, E. D. (in press). Advances in prevention science: A developmental psychopathology perspective. In D. Cicchetti (Ed.), Developmental psychopathology (Vol. 4, 3rd ed., Chap. 16). Hoboken, NJ: Wiley.

Weder, N., Zhang, H., Jensen, K., Yang, B. Z., Simen, A., Jackowski, A., et al. (2014). Child abuse, depression, and methylation in genes involved with stress, neural plasticity, and brain circuitry. Journal of the American Academy of Child \& Adolescent Psychiatry, 53, 417-424.

Yang, B. Z. Y., Zhang, H., Ge, W., Weder, N., Douglas-Palumberi, H., Perepletchikova, F., et al. (2013). Child abuse and epigenetic mechanisms of disease risk. American Journal of Preventive Medicine, 44, 101-107. 